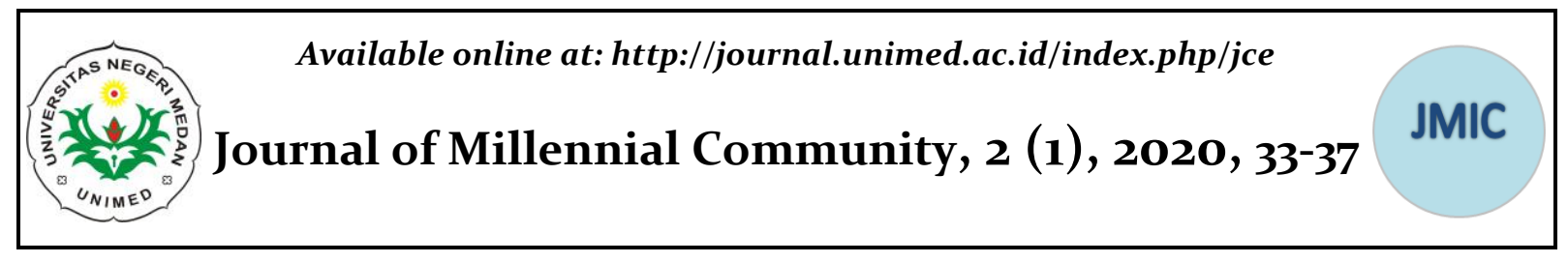

\title{
Pelatihan Pengenalan Alfabet bagi Guru PAUD di Samigaluh Kulonprogo
}

\author{
Fitta Ummaya Santi ${ }^{1}$, Alif Nurrahman ${ }^{2}$, Tri Wahyuni ${ }^{3}$, Neneng Thoyyibah ${ }^{4}$ \\ 1234 Universitas Negeri Yogyakarta \\ Email: fitta us@uny.ac.id
}

\begin{abstract}
Abstrak
Penelitian ini bertujuan untuk mengembangkan kemampuan guru PAUD dalam mengenalkan alfaabet dengan memanfaatkan sumber belajar sekitar. Penelitian ini merupakan penelitian tindakan dengan tahapan perumusan masalah, perencanaan, implementasi tindakan, dan refleksi. Tindakan berupa pemberian pelatihan kepada para 19 guru PAUD di Samigaluh, Kulonprogo. Data dikumpulkan dengan wawancara dan observasi dan dianalisis secara kualitatif yaitu reduksi, penyajian data dan penarikan kesimpulan. Teknik keabsahan data dilakukan dengan pengamatan perpanjangan dan triangulasi. Hasil penelitian menunjukkan bahwa pelatihan yang diberikan kepada kelompok sasaran memberikan dampak positif. Pendidik memiliki pengetahuan dan keterampilan dalam mengenalkan alfabet kepada anak dengan metode dan media yang menyenangkan. Guru mampu membuat dan mengkreasikan media belajar dengan sumber-sumber alam yang ada disekitar.
\end{abstract}

Kata Kunci: pelatihan, alphabet, paud

\section{Alphabet Introductory Training for Early Child Teachers in Samigaluh Kulonprogo}

\begin{abstract}
This study aims to develop the ability of PAUD teachers in introducing the alphabet by utilizing learning resources around. This research is an action research with the stages of problem formulation, planning, implementation of actions, and reflection. The action took the form of providing training to 19 PAUD teachers in Samigaluh, Kulonprogo. Data collected by interview and observation and analyzed qualitatively that is reduced, presented and drawn conclusions. The validity of the data is done by observing the extension and triangulation. The results showed that the training provided to the target group had a positive impact. Educators have the knowledge and skills in introducing Alfabet to children with fun methods and media. The teacher is able to create and create learning media with natural resources that are around.

Keywords: training, alphabet, paud
\end{abstract}

\section{PENDAHULUAN}

Pendidikan Anak Usia Dini (PAUD) merupakan peletak pondasi dasar pendidikan selanjutnya. Masa anak usia dini disebut dengan masa golden age. Masa ini, perkembangan kecerdasan anak sangat cepat dan mudah dalam menangkap segala informasi yang diperolehnya. Dalam Undang-undang nomor 20 tahun 2003 tentang sistem pendidikan nasional bahwa pendidikan anak usia dini adalah suatu upaya pembinaan yang ditujukan kepada anak sejak lahir hingga usia enam tahun 
yang dilakukan melalui pemberian rangsangan pendidikan untuk membantu pertumbuhan dan perkembangan jasmani dan rohani agar anak memiliki kesiapan dalam pendidikan selanjutnya.

Pendidikan pada anak usia dini pada dasarnya meliputi seluruh upaya dan tindakan yang dilakukan oleh pendidik dan orang tua dalam proses perawatan, pengasuhan dan pendidikan pada anak dengan menciptakan aura dan lingkungan dimana anak dapat mengeksplorasi pengalaman yang memberikan kesempatan kepadanya untuk mengetahui dan memahami pengalaman belajar yang diperolehnya dari lingkungan, melalui cara mengamati, meniru dan bereksperimen yang berlangsung secara berulang ulang dan melibatkan seluruh potensi dan kecerdasan anak (Sujiono, 2013, p.7).

Adapun aspek perkembangan anak usia dini terdiri dari beberapa aspek. Pertama, perkembangan moral dan agama. Pada aspek perkembangan agama dan moral anak usia 5-6 tahun memiliki beberapa indikator pencapaian perkembangan yaitu mengenal agama yang dianut, meniru gerakan ibadah dengan urutan yang benar, mengucapkan salam dan membalas salam. Kedua, perkembangan fisik motorik. Perkembangan fisik motorik terbagi atas tiga yaitu motorik kasar, motorik halus dan kesehatan dan perilaku keselamatan. Ketiga, aspek perkembangan kognitif memiliki tiga bagian yaitu belajar dan pemecahan masalah, berfikir logis, dan berpikir simbolik. Keempat, aspek perkembangan bahasa memiliki dua bagian yaitu memahami bahasa dan mengungkapkan bahasa. Kelima, perkembangan sosial emosional.

Salah satu perkembangan yang harus dikuasai anak usai dini adalah kemampuan berbahasa. Bahasa adalah simbol untuk menyatakan ide dan informasi. Termasuk didalamnya adalah kemampuan membaca. Tingkat pencapaian perkembangan bahasa pada anak usia 5-6 tahun dalam Kurikulum pengembangan program di Taman KanakKanak antara lain; anak mampu menyebutkan simbol-simbol huruf yang dikenal, suara huruf awal dari nama benda-benda yang ada di sekitarnya, menyebutkan kelompok gambar yang memiliki bunyi/huruf awal yang sama, memahami hubungan antara bunyi dan bentuk huruf, membaca nama sendiri, menuliskan nama sendiri dan sebagainya.

$$
\text { Farida Rahim (2008: 16) yang }
$$

mengatakan bahwa faktor yang mempengaruhi membaca permulaan salah satunya adalah faktor intelektual yang secara umum, intelegensi anak tidak sepenuhnya mempengaruhi berhasil atau tidaknya anak dalam membaca permulaan. Selain itu adalah faktor metode mengajar guru, prosedur dan kemampuan guru juga turut mempengaruhi kemampuan membaca permulaan anak.

Membaca permulaan dapat diartikan suatu tahap awal yang dilakukan oleh anak untuk memperoleh kecakapan dalam membaca. Yaitu kemampuan atau keterampilan mengenal tulisan sebagai lambang atau simbol bahasa, sehingga anak dapat mensuarakan tulisan tersebut. Membaca permulaan bagi anak adalah tahap awal anak belajar mengenal huruf atau simbol bunyi dan mensuarakannya, sebagai dasar anak dalam pembelajaran membaca berikutnya (Suhartono, 2005, pp.191-192)

Masa anak usia dini dikenal dengan masa bermain. Maimunah Hasan (2009) Pengenalan huruf sejak usia PAUD adalah metode pengajarannya melalui proses sosialisasi, dan metode pengajaran membaca tanpa membebani dengan kegiatan belajar yang menyenangkan.

Selain penggunaan metode yang beragama, media juga sangat dianjurkan dalam membelajarkan anak usia dini. Arif Sadiman (2006), media adalah segala sesuatu yang dapat menyalurkan pesan dari pengirim ke penerima sehingga dapat merangsang pikiran, perasaan, perhatian, minat, serta perhatian siswa sedemikian rupa sehingga proses belajar terjadi.

Tentu, peran penting pendidik di sekolah sangat diperlukan. Keberhasilan pendidikan anak usia dini di sekolah terletak pada guru. Guru harus dapat mengarahkan, membimbing dan memberikan contoh kepada anak didiknya. 
Berdasarkan hasil observasi di PAUD, didapatkan hasil bahwa kemampuan guru dalam mengajarkan alphabet kepada anak didik masih kurang variatif. Hal ini lah yang menyebabkan anak didik kurang tertarik dalam belajar dan kurang mudah menangkap informasi. Selain itu juga kurangnya pengetahuan dan keterampilan guru dalam mengembangkan media pembelajaran menggunakan bahan-bahan di alam. Guru selama ini hanya menggunakan media yang sudah tersedia di toko dengan penyampian yang kurang bervariasi. Oleh sebab itu, tidak mengherankan apabila hasil kegiatan pembelajaran yaitu anak ramai saat dikelas dan pembelajaran cenderung mombosankan. Dari permasalahan yang di gambarkan di atas maka perlu dicari upaya agar pembelajaran yang dapat menyenangkan bagi anak sehingga anak dapat aktif dan antusias mengikuti kegiatan belajar pra-membaca. Upaya yang dapat dilakukan adalah melatih guru-guru untuk lebih kreatif dalam mengembangkan media pembelajaran di sekolah dengan bahan yang ada disekitar. Media lain yang dapat digunakan adalah media alphabet book smartkids untuk meningkatkan minat belajar kepada anak, meningkatkan kreativitas belajar dengan kegiatan belajar beragam dan menumbuhkan rasa ingin tahu terhadap alphabet. Selain itu juga diharapkan memberikan pengetahuan dan keterampilan kepada guru untuk mengembangkan media dan membelajarkan alphabet pada anak usai dini.

\section{METODE}

Penelitian ini menggunakan
pendekatan action research yang
dimaksudkan untuk mengembangkan
kemampuan mengajar guru PAUD di
Samigaluh Kulonprogo. Penelitian ini
dilaksanakan pada bulan April - Juni 2019
kepada 19 guru PAUD yang berlokasi di TK
Al Islam Madigondo. Model penelitian
tindakan yang digunakan adalah model
penelitian tindakan partisipatoris yang
menekankan para kemitraan pada proses
pembelajaran. Pelaksanaan kegiatan bersifat
siklus/spiral yaitu: memahami isu/masalah,

merencanakan tindakan, mengimplementasikan tindakan dan merefleksi untuk memperbaiki rencana tindakan (McIntyre, 2007). Pengumpulan data dilakukan dengan wawancara dan observasi sesuai dengan pelaksanaan pada masing-masing tahapan penelitian tindakan dimaksud. Wawacara dilakukan kepada guru PAUD yang dilatih, orangtua siswa, dan anak-anak PAUD.

\section{HASIL DAN PEMBAHASAN}

Kegiatan pelatihan ini melalui beberapa tahapan yaitu:

\section{Tahap Perencanaan}

Pada tahap ini ada beberapa kegiatan yang dilakukan yaitu menjalin kerjasama dengan pihak-pihak terkait, membuat matrik kegiatan, menyiapkan materi untuk kegiatan, menyiapkan alat dan bahan, dan materi pelatihan. Kerjasama dilakukan dengan guru-guru PAUD di Samigaluh.

\section{Tahap Pelaksanaan}

Pelaksananan dilakukan sebanyak 3 kali pertemuan dengan sasaran guru PAUD yang terdapat di desa Madigondo. Pada tahap ini ada beberapa kegiatan yang telah terlaksana diantaranya yaitu:

a. Sosialisasi

Kegiatan sosialisasi dilakukan guna memberikan informasi akan dilaksanakannya kegiatan pelatihan ini. Kegiatan ini telah dilaksanakan pada tanggal 22 April 2019 di TK Islam Al Qur'an Madigondo. Disini pengabdi mengenalkan anggota tim dan melakukan analisis kebutuhan dan berdiskusi untuk mengumpulkan informasi terkait cara-cara pembelajaran pengenalan alfabet yang dilakukan selama ini. Pada kegiatan ini dijelaskan pula pentingnya pengenalan alphabet pada usia dini. Kegiatan sosialisasi dilakukan dengan diskusi atau tanya jawab tim kepada peserta pelatihan yang digunakan sebagai penguat program yang akan dilaksanakan.

b. Pengenalan bahan alam

Kegiatan ini telah dilaksanakan pada hari Sabtu tanggal 11 Mei 2019 bertempat di TK Islam Al Qur'an 
Madigondo. Kegiatan berupa pengenalan bahan-bahan alam yang dapat dimanfaatkan untuk media pengenalan alphabet. Bahan alam yang tersedia di sekitar dan mudah ditemui diantaranya: batu, daun, ranting, dll. Pentingnya pengenalan bahan alam untuk membangun kesadaran bahwa sumbersumber alam yang tersedia di sekitar merupakan sumber media yang dapat dimanfaatkan dalam pembelajaran.

c. Pelatihan pembuatan media dengan bahan alam

Kegiatan ini telah dilaksanakan pada Sabtu tanggal 11 Mei 2019 di TK Islam Al Qur'an Madigondo. Pelatihan berupa pengenalan alphabet mengunakan bahan terdapat pada alam seperti daun, tanah liat dan lidi. Daun dan lidi dipotong kemudian dibentuk menyerupai huruf alphabet dan ditempelkan diatas kertas HVS. Media alam tanah liat dibentuk menyerupai hewan atau buah-buahan. Tanah liat yang telah dibentuk diberi tulisan alphabet, seperti contoh "P" untuk pisang. Untuk menarik perhatian anak usia dini, tanah liat diwarnai dengan cat warna dan diberi penghias gliter.

Selain tanah liat, penggunaan lidi untuk pengenalan alphabet yaitu dengan memotong-motong lidi dan menempelkannya pada kertas dengan membentuk huruf yang diinginkan. Begitu pula dengan daun. Daun digunting menyerupai huruf yang diinginkan. Kemudian ditempel pada kertas sebagai media pembelajaran.

d. Pengenalan Alphabet dengan media Alphabet book Smartkids

Alphabet book smart kids merupakan media yang dibuat oleh pengabdi sebagai upaya melengkapi media bahan alam yang sudah diajarkan. Kegiatan ini telah dilaksanakan pada hari sabtu tanggal 18 Mei 2019 di TK Islam Al Qur'an Madigondo. Alphabet book smart kids berupa buku dan perangkatnya, dimana anak mencocokkan huruf atau gambar yang terdapat pada buku tersebut. Pelatihan yang dilakukan dengan metode ceramah dan demonstrasi. Produk alphabet book smarkids dikenalkan guna membantu guru dalam mengenalkan alphabet pada anak usia dini. Didalam media pembelajaran tersebut terdapat pengenalan alpahabet dengan cara pencocokan alphabet kapital dengan kecil dan variasi tema hewan, buah, dan benda-benda di sekitar.

e. Pendampingan

Kegiatan pendampingan dan observasi dilakukan selama 2 kali, yaitu pada hari kamis tanggal 13 Juni 2019 dan Sabtu tanggal 15 Juni 2019. Pendampingan dilakukan untuk mengetahui bagaimana guru menerapkan hasil pelatihan yang diperolehnya. Tim pengabdi mengobservasi dan memberikan pendampingan dengan melihat bagaimana guru dalam mengajar pengenalan alfabet kepada peserta didik.

Hasilnya menunjukkan bahwa guru sudah mampu menerapkan hasil pelatihan yang diperolehnya. Hal ini dapat dilihat dari anak yang antusias mengikuti pengenalan alphabet dengan media alam. Perhatian anak terfokus kepada materi pembelajaran alphabet dan anak menunjukkan kreativitasnya dalam membentuk alphabet berbahan tanah liat, daun, lidi dengan imajinasi mereka.

Berdasarkan kegiatan yang telah dilakukan terdapat perubahan pada guru-guru PAUD di desa Madigondo tersebut. Perubahan tersebut meliputi: 1) Pengetahuan. Guru/ pendidik PAUD memiliki pengetahuan bagaimana memanfaatkan bahan-bahan yang ada di alam sekitar untuk mengenalkan alphabet; 2) Guru lebih kreativitas dalam mengenalkan alphabet pada anak dengan metode dan media yang beragam, sehingga anak juga merasa senang dan tidak bosan; 3) penggunaan alphabet book smartkids menjadikan media lebih bervariasi dan pembelajaran yang menyenangkan sambil bermain.

Keberlanjutan program. Kegiatan ini diharapkan dapat dikembangkan oleh pendidik PAUD di sekolahnya dan dapat 
ditularkan kepada guru yang lain. Tim Pengabdi sudah membagikan media pembelajaran alphabet book smart kids sehingga dapat diterapkan kepada anak didik peserta pelatihan untuk pengenalan alfabet.

Tabel 1. Materi Pelatihan

\begin{tabular}{cl}
\hline No. & Materi Pelatihan \\
\hline 1. & Pengenalan Sumber Alam \\
2. & Pelatihan membuat Media \\
3. & Penerapan Media dalam \\
& Pembelajaran \\
4. & Pendampingan \\
\hline
\end{tabular}

Berdasarkan hasil kegiatan yang telah dilakukan memberikan dampak positif bagi guru-guru khususnya juga anak-anak PAUD. Walaupun pengenalan alphabet belum boleh diberikan di PAUD, setidaknya dengan media dan metode yang menyenangkan anak tidak merasa tertekan dalam belajar. Kegiatan ini lebih pada pengenalan alphabet yang dilakukan dengan bermain.

Melalui media tersebut, anak lebih tertarik untuk belajar. Sehingga kegiatan belajar dapat berjalan dengan lebih menarik, anak bergairah dan termotivasi untuk belajar.

\section{SIMPULAN}

Program pengenalan alfabet anak usia dini bertujuan untuk memberikan pelatihan kepada guru dalam memanfaatkan sumber alam sebagai media pembelajaran pengenalan Alfabet dan pengenalan media Alphabet Book Smartkids yang sudah dibuat oleh tim pengabdi. Hasil yang di capai dari program ini adalah meningkatkan pengetahuan dan keterampilan guru menjadi lebih kreatif dan variatif dalam pembelajaran Alphabet untuk anak usia dini, selain itu guru dapat mengembangkan dan memanfaatkan media bebasis bahan-bahan lokalyang tersedia di lingkungan dengan sesuai kondisi geografisnya.
Anak-anak usia dini menjadi lebih bersemangat dalam belajar sehingga timbul kreativitas untuk lebih mengeksplore media Alphabet Book Smart Kids dan media dari alam dan barang bekas. Hal ini dapat dilihat dari perubahan peserta pelatihan (guru) sebelum dan sesudah mendapat program. Peserta pelatihan sangat bersemangat dan antusias mengikuti pelatihan dan langsung mempraktekkannya di lembaga PAUD masing-masing. Dengan program ini mendukung kegiatan guru-guru PAUD dalam mengasah ketrampilan dan kreativitas dalam profesinya sebagai guru PAUD.

Harapannya kegiatan ini bisa dilanjutkan kepada pendidik PAUD yang lain, sehingga proses mendidik anak menyenangkan dengan beragam media yang variatif.

\section{DAFTAR PUSTAKA}

Maimunah Hasan. (2009). Pendidikan Anak Usia Dini (PAUD). Yogyakarta. Diva Press

Rahim, F. 2008. Pengajaran Membaca di Sekolah Dasar. Jakarta: PT Bumi Aksara.

Arif Sadiman, dkk. (2016). Media Pendidikan, Pengertian, Pengembangan, dan Pemanfaatannya. Jakarta: PT Raja Grafindo Persada

Suhartono. (2005). Perkembangan bicara anak usia dini. Jakarta: Dinas Pendidikan Nasional Direktorat Jendral Perguruan Tinggi

Sujiono, N. Y. (2013). Konsep dasar pendidikan anak usia dini. Jakarta: PT Ideks

\section{PROFIL SINGKAT}

Fitta Ummaya Santi. Merupakan dosen PLS FIP UNY. Lahir di Kebumen, 28 Maret 1987. Jenjang Pendidikan SI di PLS UNY lulus tahun 2009, dan melanjutkan S2 PLS di Pascasarjana UNY lulus tahun 2012. 